\title{
Effects of Phosphorus on Shoot and Root Growth, Partitioning, and Phosphorus Utilization Efficiency in Lantana
}

\author{
Hye-Ji Kim ${ }^{1,4}$ \\ Department of Horticulture and Landscape Architecture, Purdue University, \\ West Lafayette, IN 47907-2010 \\ Xinxin $\mathbf{L i}^{2,3}$ \\ Department of Tropical Plant and Soil Sciences, University of Hawaii at \\ Manoa, Honolulu, HI 96822-2279
}

Additional index words. phosphorus requirement, fertilizer rates, nutrient use efficiency, uptake, growth stage, root-to-shoot ratio, greenhouse production

\begin{abstract}
This study was undertaken to critically analyze the effects of reduced phosphorus (P) on shoot and root growth, partitioning, and phosphorus utilization efficiency (PUtE) in lantana (Lantana camara 'New Gold'). Plants were grown in a 1:1 mixture of perlite and vermiculite with complete nutrient solutions containing a range of $P$ concentrations considered to be deficient $\left(1 \mathrm{mg} \cdot \mathrm{L}^{-1}\right)$, low $\left(3\right.$ and $\left.5 \mathrm{mg} \cdot \mathrm{L}^{-1}\right)$, adequate $\left(10 \mathrm{mg} \cdot \mathrm{L}^{-1}\right)$, and high (20 and $\left.30 \mathrm{mg} \cdot \mathrm{L}^{-1}\right)$. Higher $P$ supply had most dramatic effect on increasing the number of leaves and leaf surface area, subsequently leading to a disproportionate increase in shoot biomass than root biomass. Increasing $P$ from 1 to $30 \mathrm{mg} \cdot \mathrm{L}^{-1}$ linearly $(P<0.0001)$ increased shoot dry weight $(\mathrm{DW})$ during vegetative growth, and logarithmically $(P<$ 0.0001) during reproductive growth. Regardless of plant growth stage, biomass of roots and flowers (inflorescences) logarithmically increased $(P<0.0001)$ with increasing $P$ concentrations. Plants grown with lower $P$ allocated more biomass to roots than shoots, resulting in a higher root-to-shoot ratio. Increasing $P$ concentration to $20 \mathrm{mg} \cdot \mathrm{L}^{-1}$ increased the accumulation of $P$ in all plant parts, but predominantly in shoots, whereas further increasing the concentration increased the accumulation primarily in roots and flowers. Higher $P$ accumulation in plant tissues did not strongly contribute to the biomass production. Phosphorus utilization efficiency was higher with lower $P$ supply in all plant tissues. P-deficient roots had the highest PUtE and specific root length (SRL), and retained higher proportion of $P$ compared with nondeficient roots. Our results indicate that $P$ concentration at $20 \mathrm{mg} \cdot \mathrm{L}^{-1}$ is sufficient to maintain optimal vegetative growth while reproductive growth does not require $P$ concentrations over $10 \mathrm{mg} \cdot \mathrm{L}^{-1}$ as it stimulates greater level of $P$ accumulation in plant parts with little or no effect on growth and flowering, and biomass accumulation in lantana.
\end{abstract}

Phosphorus is an essential nutrient for plant growth and reproduction. Intensive use of $P$ fertilizers for crop production has led to

\footnotetext{
Received for publication 20 Nov. 2015. Accepted for publication 5 July 2016.

This research was supported by U.S. Department of Agriculture (USDA) National Institute of Food and Agriculture (NIFA), and Multistate Hatch project NC-1186 (accession number 224879).

We thank Craig Okazaki and Ronald Matsuda for greenhouse assistance in conducting the experiments, Russell Yost for equipment support, and Leilani Nursery for plant material.

Any opinions, findings, conclusions, or recommendations expressed in this publication are those of the author(s) and do not necessarily reflect the view of the U.S. Department of Agriculture.

${ }^{1}$ Assistant Professor.

${ }^{2}$ Visiting Scholar.

${ }^{3}$ Current address: State Key Laboratory for Conservation and Utilization of Subtropical Agro-Bioresources, Root Biology Center, South China Agricultural University, Guangzhou 510642, PR China.

${ }^{4}$ Corresponding author. E-mail: hjikim@purdue.edu.
}

precisely determine the $\mathrm{P}$ requirements of crops to ensure crop production and meet the growing environmental challenges.

A large number of studies have shown that early season $\mathrm{P}$ supply is critical for optimum crop yield of many field-grown crops (Grant et al., 2001), which might have led to the practice of providing $\mathrm{P}$ starter fertilizers for greenhouse and nursery crop production, and this practice is still common. Superphosphate is routinely incorporated into potting media followed by regular fertilization with either liquid fertilizer or controlled-release fertilizer containing $\mathrm{P}$ (Wright and Niemiera, 1987). Excessive concentrations of $\mathrm{P}$ have been applied for crop production during this practice, exaggerating the risk of $\mathrm{P}$ runoff to the environment. Little is known about optimum $P$ rates for most greenhouse and nursery crop production (Bailey and Nelson, 2004; Warncke and Krauskopf, 1983), and therefore, P fertilizer has been applied far in excess of what is required to achieve high crop productivity. For example, in conventional horticultural production systems, plants are often grown with $\mathrm{P}$ concentrations ranging from 90 to 150 $\mathrm{mg} \cdot \mathrm{L}^{-1}$ to compensate for the lack of buffering capacity of soilless media (Bjerregård and Hansen, 1983; Williams and Nelson, 1996). Current application rates of $P$ largely depend on nitrogen fertilizer recommendations. Due to a general perception that $\mathrm{P}$ stimulates root growth and helps the transplants to obtain a quick establishment, the application of fertilizers with low N:P ratios is still common (Broschat and Klock-Moore, 2000; Hansen and Lynch, 1998; Williams and Nelson, 1996). Alternatively, the fertilizers with a ratio of 2:1:2 are often recommended for commercial greenhouse crops (Nelson, 1996; Whitcher et al., 2005).

A few studies have been conducted to determine an optimum $\mathrm{P}$ concentration for container crop production (Wright and Niemiera, 1987). $\mathrm{P}$ applications of $\approx 10 \mathrm{mg} \cdot \mathrm{L}^{-1}$ in the irrigation water have resulted in maximum growth of Ilex crenata (Yeager and Wright, 1982) and Chamaecyparis lawsoniana (Van der Boon, 1981), which was also true for the rooted cuttings of Rhododendron and Cotoneaster adpressus praecox (Havis and Baker, 1985). Meanwhile, maximum growth was achieved in Vinca and new guinea impatiens grown at $\mathrm{P}$ concentration around $20 \mathrm{mg} \cdot \mathrm{L}^{-1}$ (Whitcher et al., 2005). Plant growth, biomass accumulation, and $\mathrm{P} d y-$ namics can be affected during the transition from vegetative to reproductive growth as demonstrated in chrysanthemum (Hansen and Lynch, 1998). Therefore, plant growth stage should be considered when determining $P$ requirement of a crop. Many additional factors can affect $P$ requirement of the crop including growing media, and irrigation method and frequency (Majsztrik et al., 2011); however, it is important to define a baseline $\mathrm{P}$ concentration required for an optimum plant growth and the implications of such a baseline without interference with other factors. 
The effects of $\mathrm{P}$ on root growth and rootto-shoot ratio present conflicting results among the studies on container crops. According to Harris (1992), authors of several publications state or imply that $\mathrm{P}$ fertilizations primarily stimulate root growth, while other studies reported that increasing $\mathrm{P}$ supply increased root growth but decreased rootto-shoot ratio (Hansen and Lynch, 1998; Kim et al., 2008; Lynch et al., 1991), or it had no effect on root growth or root-toshoot ratio (Broschat and Klock-Moore, 2000; Dufault and Schultheis, 1994; Ristvey et al., 2007). Little is known about the $P$ accumulation patterns and PUtE in container crops, and there are only a few reports on the effects of $\mathrm{P}$ fertilization on partitioning in relation to their productivity. Such information is critical as it will help design more efficient management strategies for $\mathrm{P}$ fertilizer by better aligning the $\mathrm{P}$ requirements of crops and the application amount and timing of the nutrient. An understanding of such relationships is important to determine sustainable management practices for $\mathrm{P}$ fertilization. The objective of this experiment was to critically analyze the effects of $\mathrm{P}$ on shoot and root growth, $\mathrm{P}$ partitioning, and PUtE in lantana (L. camara 'New Gold'). Our results will aid in refining the effects of $\mathrm{P}$ on plant growth and flowering in ornamental crops, and establishing the best $\mathrm{P}$ management practices.

\section{Materials and Methods}

Plant growth and culture methods. Rooted cuttings of $L$. camara 'New Gold' were obtained from Leilani Nursery in Waimanalo, HI, and uniform cuttings were chosen and transplanted into $15-\mathrm{cm}$-diameter pots filled with $1: 1(\mathrm{v} / \mathrm{v})$ perlite and vermiculite. The plants were grown at Magoon Greenhouse Facility, University of Hawaii at Manoa, without supplemental irradiance. Day and night temperatures in the greenhouse during the experimental periods averaged $24.4 \pm 2.4{ }^{\circ} \mathrm{C}$ and $20.9 \pm 0.5{ }^{\circ} \mathrm{C}$ and $28 \pm 4{ }^{\circ} \mathrm{C}$ and $23 \pm 2{ }^{\circ} \mathrm{C}$, respectively. Relative humidity was $55 \% \pm 5$ and $64 \% \pm$ 5 (day/night). Photosynthetically active radiation varied throughout the day with a maximum of $1000 \mu \mathrm{mol} \cdot \mathrm{m}^{-2} \cdot \mathrm{s}^{-1}$. Plants were completely randomized for two harvest times. Each harvest consisted of six plants. The first six plants were randomly chosen and harvested after 3 weeks and the remaining six after 7 weeks. The experiment was conducted twice.

P treatment. Plants were fertigated at each irrigation with half-strength modified Hoagland's nutrient solution (Epstein and Bloom, 2005; Hoagland and Arnon, 1950) containing $2500 \mu \mathrm{M} \mathrm{KNO}_{3}, 2500 \mu \mathrm{M} \mathrm{Ca}\left(\mathrm{NO}_{3}\right)_{2} \cdot 4 \mathrm{H}_{2} \mathrm{O}$, $250 \mu_{\mathrm{M}} \mathrm{K}_{2} \mathrm{SO}_{4}, 1000 \mu \mathrm{M} \mathrm{MgSO}_{4} \cdot 7 \mathrm{H}_{2} \mathrm{O}$, $80 \mu \mathrm{M}$ Fe-EDTA, $4.5 \mu \mathrm{M} \mathrm{MnCl}_{2} \cdot 4 \mathrm{H}_{2} \mathrm{O}, 0.3 \mu \mathrm{M}$ $\mathrm{ZnSO}_{4} \cdot 7 \mathrm{H}_{2} \mathrm{O}, 0.16 \mu \mathrm{M} \mathrm{CuSO}_{4} \cdot 5 \mathrm{H}_{2} \mathrm{O}, 0.16 \mu \mathrm{M}$ $\left(\mathrm{NH}_{4}\right)_{6} \mathrm{Mo}_{7} \mathrm{O}_{24} \cdot 4 \mathrm{H}_{2} \mathrm{O}$, and $20 \mu \mathrm{M} \mathrm{H}_{3} \mathrm{BO}_{3}$, which was adjusted to provide a nitrogen concentration of $7.5 \mathrm{~mm}\left(105 \mathrm{mg} \cdot \mathrm{L}^{-1}\right)$. An aqueous solution of $500 \mu \mathrm{M} \mathrm{KH}_{2} \mathrm{PO}_{4}$ was applied to provide $\mathrm{P}$ at the rate of 35,100 ,
$200,335,665$, or $1000 \mu \mathrm{M}(1,3,6,10,20$, or $\left.30 \mathrm{mg} \cdot \mathrm{L}^{-1}\right)$ as final concentration. These concentrations were considered to be deficient $\left(1 \mathrm{mg} \cdot \mathrm{L}^{-1}\right)$, low $\left(3\right.$ and $\left.5 \mathrm{mg} \cdot \mathrm{L}^{-1}\right)$, sufficient (10 mg. $\mathrm{L}^{-1}$ ), and high (20 and $30 \mathrm{mg} \cdot \mathrm{L}^{-1}$ ), respectively. Fertigation was done every other day during the first 3 weeks, and every day for the rest of the weeks as plants grew bigger. The nutrient solution was adjusted to the $\mathrm{pH} 5.9$ to 6.1 before fertigation.

Data collections. Plants grown were harvested at 3 and 7 weeks after transplanting. Plant height, branch number (longer than $5 \mathrm{~cm}$ ), and leaf number (longer than $3 \mathrm{~cm}$ ) were recorded weekly. Plant width was calculated as an average of values from two perpendicular measurements. The number of flowers (inflorescences) was counted by the number of open flowers twice every week from 4 weeks after transplanting when plants started to bloom. Flower diameter was calculated as an average of values from two perpendicular measurements. At the time of harvest, plant height, width, branch number, leaf number, and flower number were recorded again. Individual leaves longer than $1 \mathrm{~cm}$ were destructively harvested to measure leaf area with Epson Expression 10000XL (Epson America, Inc., Long Beach, CA) scanner, and leaf area was analyzed using the WinRHIZO Pro software (Regent Instrument Inc. Quebec City, QC, Canada). Fresh weight of open flowers was measured and the number of individual florets was counted.

Measurements of plant $D W$ and plant $P$ content. Shoots (leaves and stems), roots, and flowers were separated to dry in an oven set at $105^{\circ} \mathrm{C}$ for $30 \mathrm{~min}$, and then kept at $75^{\circ} \mathrm{C}$ until the samples were completely dry. The biomass was measured as DW. All plant materials were ground to a particle size of 10 mesh with a Wiley mill (Thomas Scientific, Philadelphia, PA) and $\approx 0.07 \mathrm{~g}$ samples for each treatment were used for acid digestion, and $\mathrm{P}$ content of shoots, roots, and flowers was determined using the P-molybdate blue color reaction (Murphy and Riley, 1962). The total $\mathrm{P}$ content was calculated as the sum of the content of all tissue components.

$P$ utilization efficiency. $\mathrm{P}$ utilization efficiency was defined as the total biomass produced per unit $\mathrm{P}$ accumulated in tissue ( $g$ tissue $\mathrm{DW} / \mathrm{mg} \mathrm{P}$ ) based on the definition by Rose and Wissuwa (2012). The PUtE of the shoots, roots, and flowers was calculated as the DW of the tissue divided by the total $\mathrm{P}$ content in the tissue. Similarly, the PUtE of the whole plant was determined as the sum of DWs of all plant parts divided by the total $\mathrm{P}$ content in plant tissues (g DW/mg P).

Root parameter analysis. Roots were carefully harvested and rinsed before being scanned using the Epson Expression 10000XL scanner. A representative root subsample was collected when the root system was too large to be scanned for the analysis of total root length. Root length, root average diameter, volume, and surface area were estimated using WinRHIZO Pro software. The total root length was estimated by multiplying the subsample length by the DW ratio of the scanned subsample and the total DW of the roots. Specific root length [root length per unit root dry mass $\left(\mathrm{m} \cdot \mathrm{g}^{-1}\right)$ ] was calculated by dividing the total root length by the root DW.

Allometric analysis. Shoot and root dry matter of plants harvested at 3 or 7 weeks after transplanting were used to analyze the allometric relationship of roots and shoots. The allometric relationship of the log scale DW values was fitted by linear regression and the allometric coefficient $(\mathrm{K})$ was obtained from the slope of the linear regression line (Hunt, 1990).

Statistical analysis. Plants were arranged in a completely randomized block design with six replicates. Data were analyzed with analysis of variance general linear model using Minitab (Minitab Inc., State College, PA). When the data were not normally distributed, the data were transformed with Box-Cox transformation, allowing data to be normally distributed. Pairwise comparisons between treatments were conducted using Tukey's honestly significant difference test when $\mathrm{P}$ concentration had significant effects. The whole experiment was repeated twice. Block effect was not included in the data output since we observed consistent results from the two experiments. Therefore, the data were pooled and $\mathrm{P}$ effects were tested at $P<0.05$. Best-fitting lines were determined by linear or nonlinear regression analysis using SigmaPlot 12.5 (Systat Software, Inc., Chicago, IL).

\section{Results}

Plant growth responses to $P$ availability. Lower P significantly decreased overall plant growth in lantana (Fig. 1). P-deficient plants produced considerably fewer number of leaves and branches from the first week after transplanting and remained lower throughout the growth period. The growth differences among different $\mathrm{P}$ treatment become greater over time. Despite the semitrailing growth habit of lantana, $P$ availability had significant effect on plant height, which was reduced by more than $35 \%$ in P-deficient plants compared with high $P$ plants.

The first flower opened in the 4th week after transplanting regardless of $\mathrm{P}$ concentrations, and the number of flowers rapidly increased from the following week (Fig. 1). Increasing $\mathrm{P}$ from 1 to $30 \mathrm{mg} \cdot \mathrm{L}^{-1}$ increased the number of flowers about five times; however, there were no differences when $\mathrm{P}$ concentrations were higher than $10 \mathrm{mg} \cdot \mathrm{L}^{-1}$ (Table 2).

Leaf characteristics, such as total leaf area and leaf number, were the parameters most affected by P availability (Tables 1 and 2 ). It was exponentially reduced by lower $P$, especially at the concentrations lower than $10 \mathrm{mg} \cdot \mathrm{L}^{-1}$. When $\mathrm{P}$ concentration was reduced from 30 to $10 \mathrm{mg} \cdot \mathrm{L}^{-1}$, leaf area decreased by $35 \%$ and $32 \%$ at 3 and 7 weeks, respectively. With the further reduction to $1 \mathrm{mg} \cdot \mathrm{L}^{-1}$, leaf area decreased by more than $55 \%$ and $70 \%$ at 3 and 7 weeks, respectively (Tables 1 and 2). 
A
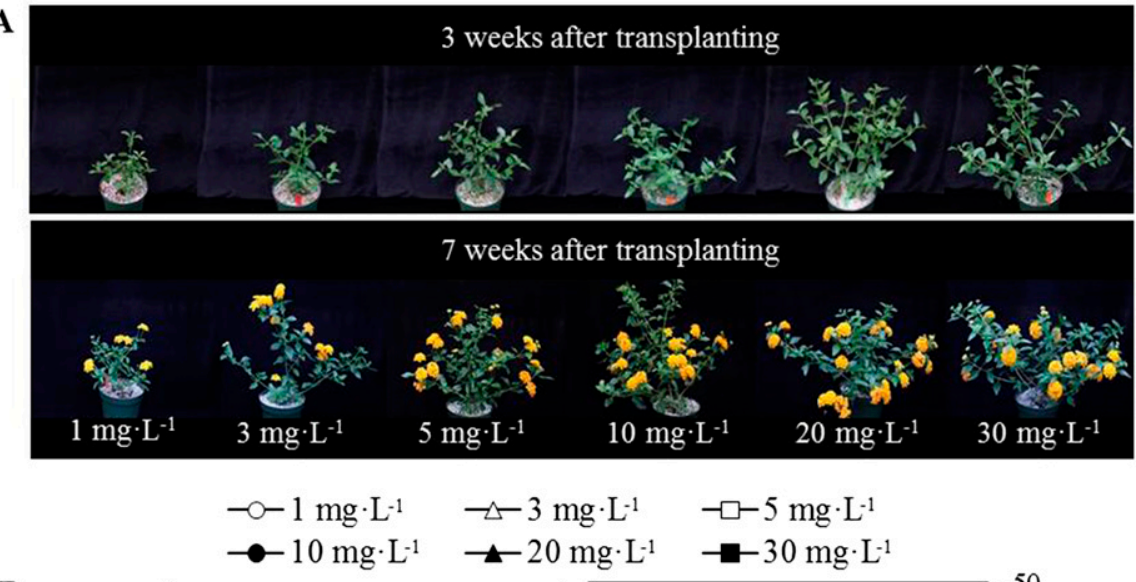

B
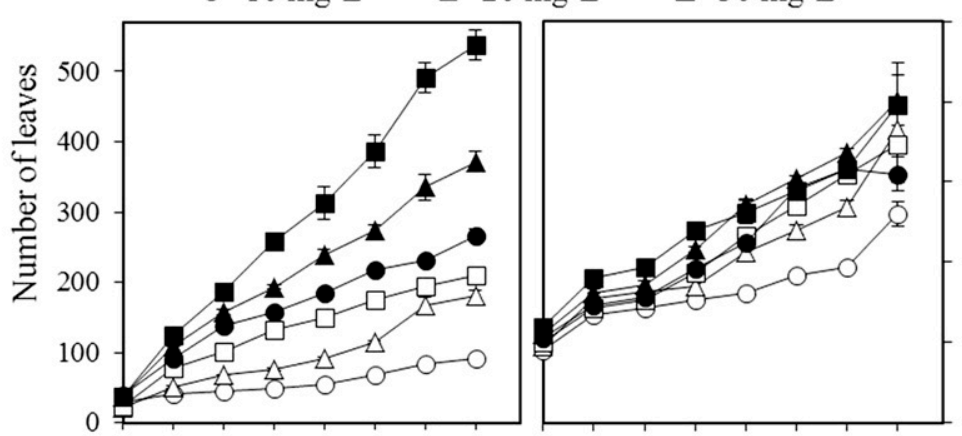

50
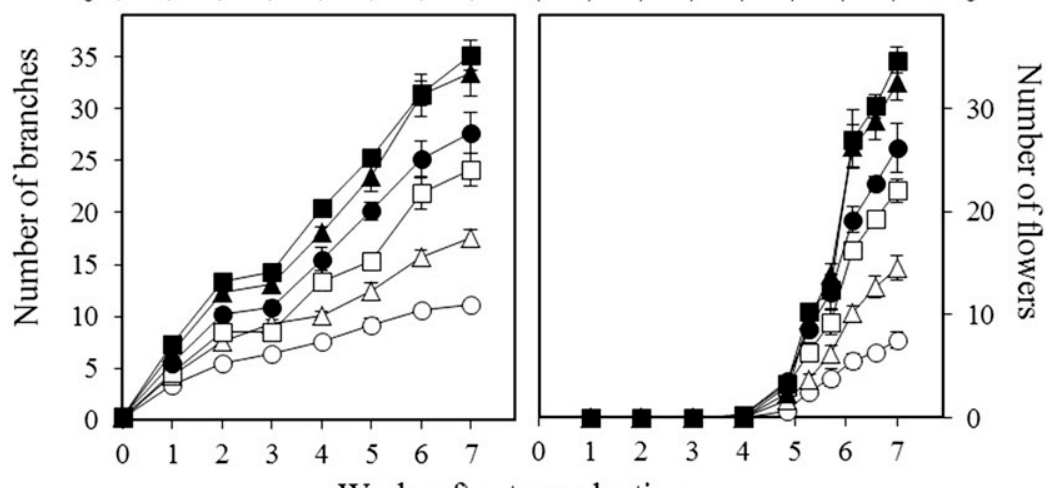

Weeks after transplanting

Fig. 1. Effects of $\mathrm{P}$ supply on plant growth of lantana. Plants were grown for 7 weeks with $\mathrm{P}$ concentrations at $1,3,5,10,20$, or $30 \mathrm{mg} \cdot \mathrm{L}^{-1}$. (A) Pictures showing differential growth of lantana at 3 weeks and at 7 weeks after transplanting. (B) Changes in vegetative and reproductive parameters over the course of production. Data shown are means of at least six plants.

The total root length, root surface area, and root volume decreased by reduced $\mathrm{P}$ at both harvests (Tables 1 and 2), while specific root length $\left(\mathrm{m} \cdot \mathrm{g}^{-1}\right)$, the ratio of root length to dry mass of fine roots, was significantly higher with reduced P. Root diameter was not different among the treatment groups at 3 weeks but tended to increase at 7 weeks as $P$ concentration was raised or lowered to the adequate level.

Biomass partitioning in response to $P$ availability. Reducing $\mathrm{P}$ concentrations from 30 to $1 \mathrm{mg} \cdot \mathrm{L}^{-1}$ decreased the total plant biomass, and more evidently in shoot than root biomass, resulting in a proportional increase in the root-to-shoot ratio (Tables 1 and 2). However, reducing $P$ from 30 to $20 \mathrm{mg} \cdot \mathrm{L}^{-1}$ did not affect the biomass of each plant part at 7 weeks after transplanting (Table 2).

Biomass accumulation and partitioning were highly influenced by $\mathrm{P}$ availability and plant growth phase. The biomass of shoots, roots, and between different growth stages, and the similar patterns of exponential decay were observed in both growth phases. Allometric coefficient is an index of the balanced growth between root and shoot components integrated at two different harvest times. The allometric analysis based on log-scale root dry mass vs. shoot dry mass for 3- and 7-week-old plants indicated that $\mathrm{P}$ concentrations had great effect on carbon allocation to roots, and plants allocated higher proportion of carbon to roots than shoots when $\mathrm{P}$ was reduced from 30 to $1 \mathrm{mg} \cdot \mathrm{L}^{-1}$ (Table 3; Fig. 3).

Flower biomass production decreased with reduced $\mathrm{P}$ due to the decrease in flower number, diameter, and area (Table 2). Although the numbers of flowers, leaves, and branches per plant were higher with increasing $\mathrm{P}$ concentrations (Table 2), these variables did not differ significantly among $\mathrm{P}$ concentrations when the results were expressed as per unit area (100 sq. $\left.\mathrm{cm}^{-2}\right)$ (Fig. 4). Similarly, the average biomass of individual flower head was not significantly different in nondeficient plants (Fig. 4A). Deficient $\mathrm{P}$ reduced the number of florets and the size of individual florets (data not shown).

$P$ accumulation in plant tissues. $\mathrm{P}$ contents in shoots, roots, and flowers increased with increasing $\mathrm{P}$ concentrations (Table 4; Fig. 5). However, plants accumulated a similar proportion of $\mathrm{P}$ in shoots $(\approx 70 \%)$ regardless of $\mathrm{P}$ availability. Total $\mathrm{P}$ content was four and five times higher in shoots than in roots and flowers, respectively. P-deficient plants accumulated a higher proportion of $\mathrm{P}$ in roots $(22 \%)$ and a lower proportion of $\mathrm{P}$ in flowers $(6 \%)$ than the roots and flowers of nondeficient plants (averagely $15 \%$ and $14 \%$, respectively) (Table 4). Although increase in $\mathrm{P}$ content in plant tissues was closely related to biomass increase, biomass accumulation occurred when $\mathrm{P}$ supply increased from deficient to adequate level (Fig. 5). Higher $P$ content in plant tissues did not strongly affect biomass accumulation as evidenced by gradual slopes (Fig. 5). Increasing $\mathrm{P}$ concentration from 10 to $20 \mathrm{mg} \cdot \mathrm{L}^{-1}$ sharply increased $\mathrm{P}$ accumulation in all plant parts, particularly in shoots, while further increasing $\mathrm{P}$ concentration from 20 to $30 \mathrm{mg} \cdot \mathrm{L}^{-1}$ accelerated $\mathrm{P}$ accumulation in roots and flowers without affecting P content in shoots (Table 4; Fig. 5).

When expressed on a tissue dry matter basis (mg P per g DW), flower P concentration was higher than the ones in shoots or roots from all $\mathrm{P}$ treatments (Table 4 ). PUtE was the highest in P-deficient plants. Plant tissues varied with PUtE, but P-deficient roots had the highest PUtE, whereas the lowest PUtE was observed in flowers, particularly in plants with sufficient $\mathrm{P}$.

\section{Discussion}

$P$ is critical during vegetative stage of growth. $\mathrm{P}$ is as an essential macronutrient that plays a vital role in plant growth, development, and reproduction. Our results show that 
Table 1. The effect of $\mathrm{P}$ supply on growth and development of lantana at 3 weeks after transplanting.

\begin{tabular}{|c|c|c|c|c|c|c|c|c|}
\hline \multirow[b]{2}{*}{ Variables } & \multicolumn{6}{|c|}{$\mathrm{P}$ concn $\left(\mathrm{mg} \cdot \mathrm{L}^{-1}\right)$} & \multirow[b]{2}{*}{$\mathrm{F}$ value } & \multirow[b]{2}{*}{$P$} \\
\hline & 1 & 3 & 5 & 10 & 20 & 30 & & \\
\hline Plant height (cm) & $15.4 \mathrm{~d}^{\mathrm{z}}$ & $17.0 \mathrm{~d}$ & $18.8 \mathrm{c}$ & $19.2 \mathrm{c}$ & $21.6 \mathrm{~b}$ & $23.9 \mathrm{a}$ & 55.5 & $* * *$ \\
\hline Plant width (cm) & $8.5 \mathrm{~d}$ & $14.5 \mathrm{~cd}$ & $19.0 \mathrm{bc}$ & $23.8 \mathrm{~b}$ & $31.5 \mathrm{a}$ & $34.3 \mathrm{a}$ & 32.1 & $* * *$ \\
\hline Branch number & $5.8 \mathrm{~d}$ & $8.0 \mathrm{c}$ & $8.4 \mathrm{bc}$ & $10.1 \mathrm{ab}$ & $10.9 \mathrm{a}$ & $11.1 \mathrm{a}$ & 18.1 & $* * *$ \\
\hline Leaf number & $45.8 \mathrm{e}$ & $56.6 \mathrm{~d}$ & $63.0 \mathrm{c}$ & $75.2 \mathrm{~b}$ & $98.3 \mathrm{a}$ & $94.6 \mathrm{a}$ & 392.8 & $* * *$ \\
\hline Leaf area $\left(\mathrm{cm}^{2}\right)$ & $144.5 \mathrm{e}$ & $231.4 \mathrm{~d}$ & $314.6 \mathrm{c}$ & $348.4 \mathrm{bc}$ & $435.9 \mathrm{~b}$ & $537.9 \mathrm{a}$ & 70.4 & $* * *$ \\
\hline Shoot dry mass (g) & $1.32 \mathrm{~d}$ & $1.93 \mathrm{~cd}$ & $2.53 \mathrm{bc}$ & $2.54 \mathrm{bc}$ & $3.26 \mathrm{~b}$ & $4.87 \mathrm{a}$ & 40.4 & $* * *$ \\
\hline Root dry mass (g) & $0.50 \mathrm{c}$ & $0.75 \mathrm{bc}$ & $0.81 \mathrm{abc}$ & $0.84 \mathrm{abc}$ & $0.95 \mathrm{ab}$ & $1.23 \mathrm{a}$ & 5.4 & $* *$ \\
\hline Total plant biomass (g) & $1.81 \mathrm{~d}$ & $2.67 \mathrm{~cd}$ & $3.34 \mathrm{bc}$ & $3.38 \mathrm{bc}$ & $4.22 \mathrm{~b}$ & $6.09 \mathrm{a}$ & 29.0 & $* * *$ \\
\hline Root-to-shoot ratio & $0.38 \mathrm{a}$ & $0.38 \mathrm{a}$ & $0.32 \mathrm{ab}$ & $0.33 \mathrm{ab}$ & $0.29 \mathrm{ab}$ & $0.25 \mathrm{~b}$ & 3.5 & $*$ \\
\hline Total root length $(\mathrm{m})$ & $37.9 \mathrm{~d}$ & $45.5 \mathrm{~cd}$ & $50.5 \mathrm{bcd}$ & $56.2 \mathrm{abc}$ & $64.0 \mathrm{ab}$ & $71.6 \mathrm{a}$ & 8.6 & $* * *$ \\
\hline Total root surface area $\left(\mathrm{cm}^{2}\right)$ & $431 \mathrm{c}$ & $545 \mathrm{bc}$ & $621 \mathrm{bc}$ & $681 \mathrm{~b}$ & $750 \mathrm{ab}$ & $903 \mathrm{a}$ & 10.1 & $* * *$ \\
\hline Total root volume $\left(\mathrm{cm}^{3}\right)$ & $3.9 \mathrm{c}$ & $5.3 \mathrm{bc}$ & $6.1 \mathrm{bc}$ & $6.6 \mathrm{~b}$ & $7.0 \mathrm{ab}$ & $9.1 \mathrm{a}$ & 10.4 & $* * *$ \\
\hline Average root diameter $(\mathrm{cm})$ & $0.36 \mathrm{a}$ & $0.39 \mathrm{a}$ & $0.39 \mathrm{a}$ & $0.38 \mathrm{a}$ & $0.37 \mathrm{a}$ & $0.40 \mathrm{a}$ & 1.6 & NS \\
\hline Specific root length $\left(\mathrm{m} \cdot \mathrm{g}^{-1}\right)$ & $80.4 \mathrm{a}$ & $71.5 \mathrm{ab}$ & $65.0 \mathrm{ab}$ & $65.0 \mathrm{ab}$ & $67.0 \mathrm{ab}$ & $52.3 \mathrm{~b}$ & 3.2 & $*$ \\
\hline
\end{tabular}

${ }^{\mathrm{z}}$ Within-row means followed by different letters are significantly different by Tukey's honestly significant difference test at $P \leq 0.05$.

Each value in the table is the mean of 6 to 12 replicates.

Two blocks were pooled for statistical analysis. Block effects were not shown.

ss, *, **, *** Nonsignificant or significant at $P \leq 0.05,0.01$, or 0.001 , respectively.

Table 2. The effect of $\mathrm{P}$ supply on growth and development of lantana at 7 weeks after transplanting.

\begin{tabular}{|c|c|c|c|c|c|c|c|c|}
\hline \multirow[b]{2}{*}{ Variables } & \multicolumn{6}{|c|}{$\mathrm{P}$ concn $\left(\mathrm{mg} \cdot \mathrm{L}^{-1}\right)$} & \multirow[b]{2}{*}{$F$ value } & \multirow[b]{2}{*}{$P$} \\
\hline & 1 & 3 & 5 & 10 & 20 & 30 & & \\
\hline Plant height $(\mathrm{cm})$ & $26.0 \mathrm{c}$ & $36.5 \mathrm{~b}$ & $34.7 \mathrm{ab}$ & $32.7 \mathrm{ab}$ & $40.2 \mathrm{a}$ & $39.5 \mathrm{a}$ & 13.26 & $* * *$ \\
\hline Plant width $(\mathrm{cm})$ & $23.3 \mathrm{~d}$ & $36.8 \mathrm{c}$ & $43.0 \mathrm{bc}$ & $47.9 \mathrm{ab}$ & $53.3 \mathrm{a}$ & $54.4 \mathrm{a}$ & 24.7 & $* * *$ \\
\hline Branch number & $11.2 \mathrm{~d}$ & $17.5 \mathrm{~d}$ & $24.2 \mathrm{c}$ & $27.7 \mathrm{bc}$ & $33.5 \mathrm{ab}$ & $35.2 \mathrm{a}$ & 36.5 & $* * *$ \\
\hline Leaf number & $91.2 \mathrm{e}$ & $181.0 \mathrm{~d}$ & $209.3 \mathrm{~d}$ & $267.0 \mathrm{c}$ & $371.3 \mathrm{~b}$ & $537.3 \mathrm{a}$ & 186.9 & $* * *$ \\
\hline Leaf area $\left(\mathrm{cm}^{2}\right)$ & $234.9 \mathrm{f}$ & $497.1 \mathrm{e}$ & $644.8 \mathrm{~d}$ & $865.1 \mathrm{c}$ & $1,026.1 \mathrm{~b}$ & $1,269.7 \mathrm{a}$ & 290.9 & $* * *$ \\
\hline Flower number & $7.5 \mathrm{~d}$ & $14.5 \mathrm{c}$ & $24.0 \mathrm{~b}$ & $26.2 \mathrm{~b}$ & $34.7 \mathrm{a}$ & $34.7 \mathrm{a}$ & 48.3 & $* * *$ \\
\hline Flower diameter $(\mathrm{cm})$ & $3.1 \mathrm{c}$ & $3.6 \mathrm{~b}$ & $4.0 \mathrm{a}$ & $4.1 \mathrm{a}$ & $4.1 \mathrm{a}$ & $4.1 \mathrm{a}$ & 58.9 & $* * *$ \\
\hline Flower area $\left(\mathrm{cm}^{2}\right)$ & $7.5 \mathrm{c}$ & $14.5 \mathrm{~b}$ & $22.0 \mathrm{a}$ & $26.2 \mathrm{a}$ & $32.5 \mathrm{a}$ & $34.7 \mathrm{a}$ & 56.3 & $* * *$ \\
\hline Shoot dry mass (g) & $2.202 \mathrm{~d}$ & $4.562 \mathrm{c}$ & $5.399 \mathrm{c}$ & $7.425 \mathrm{~b}$ & $9.623 \mathrm{a}$ & $10.774 \mathrm{a}$ & 88.6 & $* * *$ \\
\hline Root dry mass (g) & $0.758 \mathrm{c}$ & $1.569 \mathrm{~b}$ & $1.525 \mathrm{~b}$ & $2.061 \mathrm{~b}$ & $2.674 \mathrm{a}$ & $2.730 \mathrm{a}$ & 30.8 & $* * *$ \\
\hline Flower dry mass (g) & $0.095 \mathrm{e}$ & $0.453 \mathrm{~d}$ & $0.776 \mathrm{c}$ & $0.922 \mathrm{bc}$ & $1.149 \mathrm{ab}$ & $1.385 \mathrm{a}$ & 43.8 & $* * *$ \\
\hline Total plant biomass $(\mathrm{g})$ & $3.06 \mathrm{e}$ & $6.58 \mathrm{~d}$ & $7.83 \mathrm{~d}$ & $10.23 \mathrm{c}$ & $13.17 \mathrm{~b}$ & $15.04 \mathrm{a}$ & 117.3 & $* * *$ \\
\hline Root-to-shoot ratio & $0.35 \mathrm{a}$ & $0.34 \mathrm{a}$ & $0.28 \mathrm{ab}$ & $0.28 \mathrm{ab}$ & $0.28 \mathrm{ab}$ & $0.24 \mathrm{~b}$ & 3.8 & $* * *$ \\
\hline Total root length $(\mathrm{m})$ & $59.1 \mathrm{~d}$ & $73.6 \mathrm{~d}$ & $77.5 \mathrm{~cd}$ & $101.2 \mathrm{bc}$ & $124.1 \mathrm{~b}$ & $149.0 \mathrm{a}$ & 38.7 & $* * *$ \\
\hline Total root surface area $\left(\mathrm{cm}^{2}\right)$ & $690 \mathrm{~d}$ & $948 \mathrm{c}$ & $1,025 \mathrm{c}$ & $1,393 \mathrm{~b}$ & $1,620 \mathrm{ab}$ & $1,867 \mathrm{a}$ & 45.9 & $* * *$ \\
\hline Total root volume $\left(\mathrm{cm}^{3}\right)$ & $6.4 \mathrm{~d}$ & $9.8 \mathrm{c}$ & $10.8 \mathrm{c}$ & $15.3 \mathrm{~b}$ & $16.9 \mathrm{ab}$ & $18.7 \mathrm{a}$ & 40.2 & $* * *$ \\
\hline Average root diameter $(\mathrm{cm})$ & $0.37 \mathrm{c}$ & $0.41 \mathrm{ab}$ & $0.42 \mathrm{ab}$ & $0.44 \mathrm{a}$ & $0.43 \mathrm{ab}$ & $0.40 \mathrm{bc}$ & 6.6 & $* * *$ \\
\hline Specific root length $\left(\mathrm{m} \cdot \mathrm{g}^{-1}\right)$ & $78.0 \mathrm{a}$ & $57.6 \mathrm{~b}$ & $52.7 \mathrm{~b}$ & $51.2 \mathrm{~b}$ & $46.8 \mathrm{~b}$ & $47.0 \mathrm{~b}$ & 10.9 & $* * *$ \\
\hline
\end{tabular}

${ }^{\mathrm{z}}$ Within-row means followed by different letters are significantly different by Tukey's honestly significant difference test at $P \leq 0.05$.

Each value in the table is the mean of 6 to 12 replicates.

Two blocks were pooled for statistical analysis. Block effects were not shown.

Ns, *, **, *** Nonsignificant or significant at $P \leq 0.05,0.01$, or 0.001 , respectively.

reduced $\mathrm{P}$ restricts plant growth during both vegetative and reproductive growth, but more dramatically at the earlier stage of growth. However, P deficiency amplifies over time, leading to deficiency symptoms being more evident in the later stage of growth. This is particularly true for P-deficient plant, in which the total plant biomass of vegetative plant was $\approx 30 \%$ of the high $\mathrm{P}$ plant, but that of reproductive plant was only $\approx 20 \%$ (Tables 1 and 2). Similarly, P restrictions during the first 4 to 6 weeks of growth led to large reductions in tillering and head formation in wheat and barley (Grant et al., 2001), supporting our results.

It is apparent that plant growth phase plays an important role in crop biomass accumulation in response to $\mathrm{P}$ availability. Shoot biomass linearly increased with increasing concentration of $P$ during vegetative growth, while it gradually increased during reproductive growth (Fig. 2). As reported in the early finding that $\mathrm{P}$ supply is critical for many field-grown crops during early season
(Grant et al., 2001), our results indicate that higher $\mathrm{P}$ supply is important for lantana during its early growth.

Reduced $\mathrm{P}$ had a much smaller impact on reproductive plants than it does on vegetative plants. Increasing $\mathrm{P}$ concentration did not lead to a linear rapid increase in plant biomass production of reproductive plants, and flower biomass gradually increased with concomitant biomass accumulation of shoots. Reduced biomass production in reproductive nondeficient plant may be due to the decline of root growth rates compared with vegetative plant (Hansen and Lynch, 1998). P may not be actively used for root biomass production during reproductive growth due to the competition with developing flowers that may act as a stronger sink than roots for $\mathrm{P}$. Therefore, it is critical to apply $\mathrm{P}$ fertilizer based on their growth phase: high $\mathrm{P}$ during vegetative growth and sufficient $\mathrm{P}$ during reproductive growth, which is consistent with the early studies in field crops (Grant et al., 2001).
Although P supply during early development has a dominant effect on crop yield potential, $\mathrm{P}$ concentration at $20 \mathrm{mg} \cdot \mathrm{L}^{-1}$ is considered to be sufficient to maximize vegetative growth of lantana. It implies that the P supply using superphosphate or an external supply of $P$ fertilizer over this concentration does not have a positive impact on crop productivity potential. During reproductive growth, $\mathrm{P}$ accumulation in flowers is largely due to redistribution from the leaf and stem tissue (Hansen and Lynch, 1998). P supply at $10 \mathrm{mg} \cdot \mathrm{L}^{-1}$ appears to be sufficient in lantana during reproductive stage, allowing carbohydrate translocation mechanisms to function for maximum productivity (Grant et al., 2001). It should be noted that these concentrations were determined based on a perlite and vermiculite mixture in which native $P$ is considered to be negligible. Optimum $\mathrm{P}$ concentrations for crop production could vary considerably by the type of the growing medium used, and could be even lower 


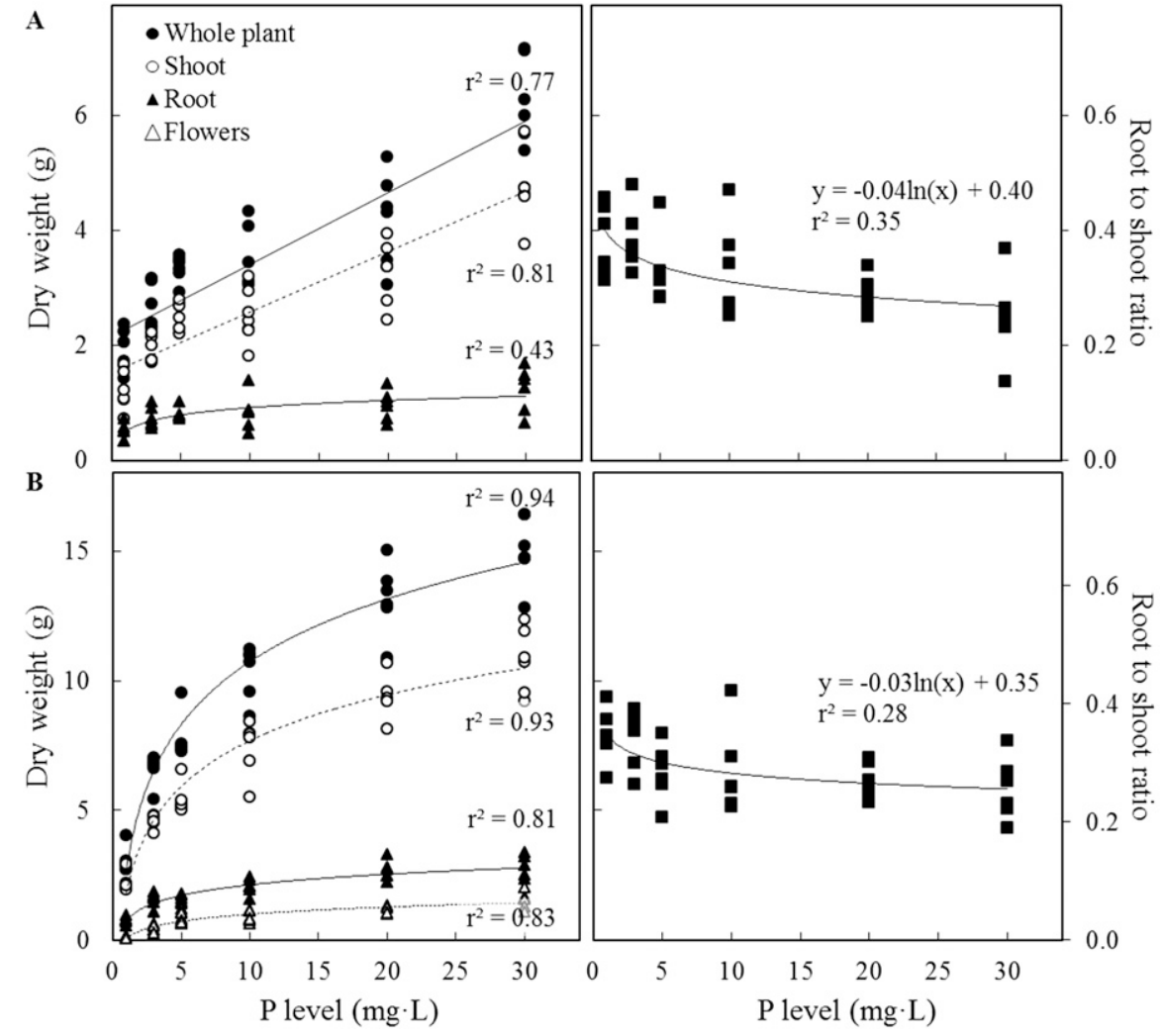

Fig. 2. The effects of $P$ supply on the dry biomass of whole plant, shoots, roots, and flowers, and root-toshoot ratio of lantana at (A) 3 weeks (vegetative stage) and (B) 7 weeks (reproductive stage) after transplanting. Linear or logarithmic regression analysis was used to response correlations. The regression line was fitted through the data for 3 weeks $(\mathbf{A})$ in whole plant $(y=0.12 x+2.20, P<0.0001)$; shoots $(y=0.10 x+1.53, P<0.0001)$; and roots $[y=0.18 \ln (x)+0.50, P<0.0001]$, and for 7 weeks $(\mathbf{B})$ in whole plant $[y=3.49 \ln (x)+2.69, P<0.0001]$; shoots $[y=2.55 \ln (x)+1.82, P<0.0001]$; roots $[y=$ $0.59 \ln (x)+0.76, P<0.0001]$; and flowers $[y=0.40 \ln (x)+0.08, P<0.0001]$.

Table 3. Allometric coefficients $(K)$ of root-toshoot ratio of lantana grown under different $\mathrm{P}$ concentrations.

\begin{tabular}{lcc}
\hline & \multicolumn{2}{c}{ Root-to-shoot ratio } \\
\cline { 2 - 3 } P concn & $K$ & $r^{2}$ \\
\hline 1 & $1.99 \mathrm{a}^{\mathrm{z}}$ & 0.83 \\
3 & $1.51 \mathrm{ab}$ & 0.87 \\
5 & $1.24 \mathrm{~b}$ & 0.80 \\
10 & $1.23 \mathrm{~b}$ & 0.78 \\
20 & $1.13 \mathrm{~b}$ & 0.86 \\
30 & $1.03 \mathrm{~b}$ & 0.85 \\
& F value from ANOVA \\
P concentration & $6.38 \quad * * *$ \\
\hline
\end{tabular}

ANOVA $=$ analysis of variance.

${ }^{z}$ Within-column means followed by different letters are significantly different by Tukey's honestly significant difference test at $P \leq 0.05$.

Each value is derived from paired measurements of root dry weight (DW) and shoot DW (Hunt, 1990) measured at 3 and 7 weeks after transplanting.

Ns, *, **, *** Nonsignificant or significant at $P \leq 0.05$, 0.01 , or 0.001 , respectively.

than $10 \mathrm{mg} \cdot \mathrm{L}^{-1}$ if $\mathrm{P}$ sources are incorporated into the medium.

Excess $P$ does not increase the number of flowers. Our observation that flower buds began to develop at 4 weeks and anthesis occurred in the same week regardless of $\mathrm{P}$ supply indicates that high $\mathrm{P}$ is not needed to promote flower initiation in lantana. Plants grown with reduced $\mathrm{P}$ produced a lower

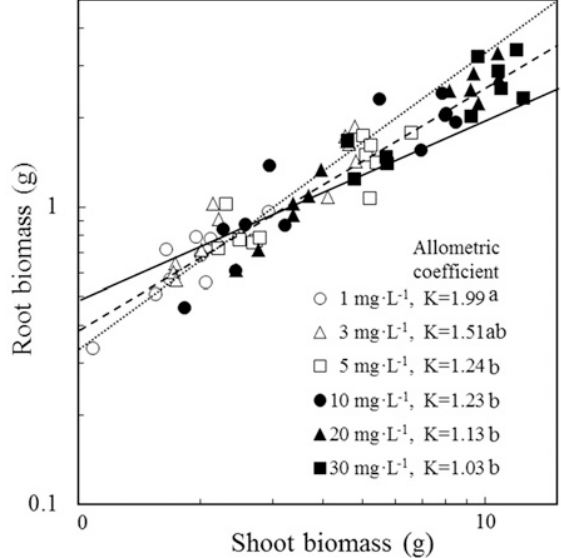

Fig. 3. The effects of $\mathrm{P}$ on allometric coefficient $(K)$ of root-to-shoot ratio. The plants were fertigated with a half-strength Hoagland's nutrient solution containing $1,3,5,10,20$, or $30 \mathrm{mg} \cdot \mathrm{L}^{-1}$ $\mathrm{P}$ on a regular basis. Data were collected at 3 and 7 weeks after transplanting. Mean values with different letters are significantly different $(P<0.05)$. The regression lines were fitted through the data for $1 \mathrm{mg} \cdot \mathrm{L}^{-1}(y=0.32 x+0.06)$ as shown in dotted line; $10 \mathrm{mg} \cdot \mathrm{L}^{-1}(y=0.23 x+$ $0.30)$ in dashed line; and $30 \mathrm{mg} \cdot \mathrm{L}^{-1}(y=0.21 x+$ 0.43 ) in solid line.

that reduced $\mathrm{P}$ decreased the size of plants without affecting productivity. These features may be used to control plant size in replacement of growth retardants that are known to reduce plant size in commercial ornamental crop production.

The effect of $P$ on root-to-shoot ratio is largely concentration dependent. Reducing $\mathrm{P}$ concentration had the most significant effect on leaf characteristics during both vegetative and reproductive stages. Reduction in leaf area and the number of leaves is characterized as the most obvious effects in P-deficient plants due to the reduced rates of cell division and expansion (Chiera et al., 2001). This is in contrast to the root growth of P-deficient plants, which was less inhibited by reduced $\mathrm{P}$, leading to a typical increase in root-toshoot ratio. It is well documented that low $\mathrm{P}$ availability increases the allocation of dry matter to roots while suppressing shoot growth, resulting in increased root-to-shoot ratios, which has been demonstrated in herbaceous species, such as chrysanthemum (Dendranthema $\times$ grandiflorum) (Hansen and Lynch, 1998), petunia (Petunia $\times$ hybrida), tomato (Lycopersicon esculentum Mill.) (Kim et al., 2008), and common bean (Phaseolus vulgaris L.) (Lynch et al., 1991). Meanwhile, some studies have shown that $\mathrm{P}$ had no effect on either root growth or root-to-shoot ratio in a wide range of plant species (Broschat and Klock-Moore, 2000; Dufault and Schultheis, 1994; Melton and Dufault, 1991; Weston and Zandstra, 1989; Yeager and Wright, 1982), in which $\mathrm{P}$ concentrations were excessively high compared with the range evaluated in our study. Our results showed that increasing $\mathrm{P}$ from 1 to $30 \mathrm{mg} \cdot \mathrm{L}^{-1}$ promotes both shoot and root growth; however, disproportionate 
growth of shoots over roots sharply decreases the root-to-shoot ratio when $\mathrm{P}$ concentration changes from deficient to low, and slightly decreases it when $\mathrm{P}$ concentration changes from low to high. It is clear that the effect of $\mathrm{P}$ on root-to-shoot ratio is largely concentration dependent. When plants experience P deficiency, growth reduction is generally greater
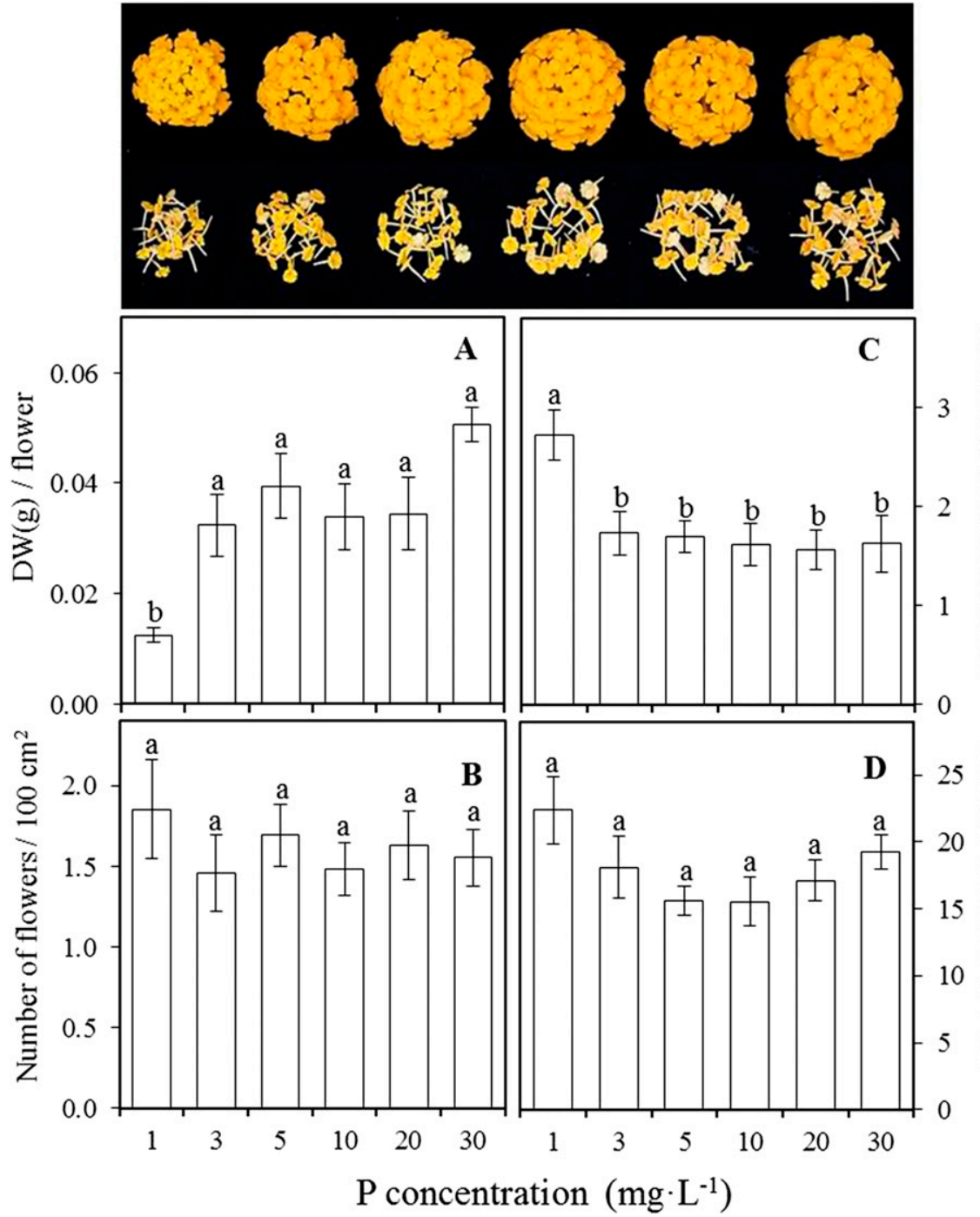

Fig. 4. The effects of $\mathrm{P}$ supply on (A) the average biomass of individual flower head, (B) the number of flowers per unit area, (C) the number of branches per unit area, and (D) the number of leaves per unit area in lantana. The top panel shows the size of flower (inflorescence) and the size and number of individual florets (left to right: 22, 25, 25, 29, 29, and 28). The plants were fertigated with a halfstrength Hoagland's nutrient solution containing 1, 3, 5, 10, 20, or $30 \mathrm{mg} \cdot \mathrm{L}^{-1} \mathrm{P}$ on a regular basis. Data were collected at 7 weeks after transplanting. Data shown are means \pm SE of at least six plants. Mean values with different letters are significantly different $(P<0.05)$. in the shoots than in the roots, allowing the plant to maintain root growth and encounter and extract $\mathrm{P}$ from the belowground environment (Grant et al., 2001). Discrepancy over the effect of $\mathrm{P}$ on root growth or root-to-shoot ratio observed in the aforementioned studies may be accounted for by the differences in $\mathrm{P}$ concentrations or the additional $\mathrm{P}$ available in the potting medium (Ristvey et al., 2007). It is obvious that reducing $\mathrm{P}$ gradually increases root-to-shoot ratio, although the significant difference can be manifested only at the extreme $\mathrm{P}$ concentrations: deficient and excess $\mathrm{P}$ supplies. Even in the studies that reported no effect of $\mathrm{P}$ on root-to-shoot ratio, it appears that the deficient to low $\mathrm{P}$ increased the root-toshoot ratio in a wide range of container-grown plants (Broschat and Klock-Moore, 2000) and in bell pepper (Capsicum annuum L.) (Dufault and Schultheis, 1994). Our allometric analysis clearly shows that reduced $\mathrm{P}$ preferentially stimulates root growth over shoot growth in lantana. It appears that allocation to root dry mass in vegetative P-deficient plants was achieved at the expense of shoot dry mass, whereas it was gained at the expense of flower dry mass in reproductive plants. The practical implication of these results is that deficient $\mathrm{P}$ supply during vegetative growth enhances root growth; however, it significantly limits plant productivity from which plant may not recover, and therefore, supplying sufficient $\mathrm{P}$ for the 3- to 4-week vegetative growth is important because it allows maximum plant growth while maintaining a balanced root-to-shoot ratio for plants to optimize resource acquisition.

$P$ requirement of lantana based on $P$ accumulation and partitioning. In this study, we used a perlite and vermiculite mixture to avoid overestimate of $\mathrm{P}$ utilization efficiencies under reduced $\mathrm{P}$ and to better quantify $\mathrm{P}$ requirements of the plant. $\mathrm{P}$ accumulation in plant tissues was highly associated with $\mathrm{P}$ supply, sharply increasing at high $\mathrm{P}$ concentrations (Fig. 5). Interestingly, increasing $\mathrm{P}$ concentration from 10 to $20 \mathrm{mg} \cdot \mathrm{L}^{-1}$ coincided with the accumulation of $\mathrm{P}$ in all plant parts, with a particularly sharp increase in shoots. Further increasing to $30 \mathrm{mg} \cdot \mathrm{L}^{-1}$ did not affect concentration in shoots but accelerated $\mathrm{P}$ accumulation in roots and flowers (Table 4; Fig. 5). These results indicate that $P$ concentration at $10 \mathrm{mg} \cdot \mathrm{L}^{-1}$ is adequate to encourage normal plant growth and reproduction of

Table 4. The effects of P supply on P content and P utilization efficiency (PUtE) of whole plant, shoots, roots, and flowers of lantana at 7 weeks after transplanting.

\begin{tabular}{|c|c|c|c|c|c|c|c|c|c|c|c|c|}
\hline \multirow{2}{*}{$\begin{array}{l}\mathrm{P} \text { concn } \\
\left(\mathrm{mg} \cdot \mathrm{L}^{-1}\right)\end{array}$} & \multicolumn{4}{|c|}{$\mathrm{P}$ content (mg/plant) } & \multicolumn{4}{|c|}{$\mathrm{P}$ concn (mg P/g dry weight) } & \multicolumn{4}{|c|}{ PUtE (g dry weight/mg P) } \\
\hline & Whole plant & Shoots & Roots & Flowers & Whole plant & Shoots & Roots & Flowers & Whole plant & Shoots & Roots & Flowers \\
\hline 3 & $6.05 \mathrm{~cd}$ & $4.22 \mathrm{~cd}$ & $1.06 \mathrm{~cd}$ & $0.76 \mathrm{~cd}$ & $0.98 \mathrm{~b}$ & $0.93 \mathrm{~cd}$ & $0.70 \mathrm{~cd}$ & $1.55 \mathrm{bc}$ & $1.14 \mathrm{~b}$ & $1.15 \mathrm{~b}$ & $1.52 \mathrm{~b}$ & $0.64 \mathrm{~b}$ \\
\hline 20 & $42.89 \mathrm{a}$ & $36.15 \mathrm{a}$ & $3.58 \mathrm{~b}$ & $3.55 \mathrm{~b}$ & $2.72 \mathrm{a}$ & $3.82 \mathrm{a}$ & $1.34 \mathrm{~b}$ & $3.59 \mathrm{a}$ & $0.32 \mathrm{~d}$ & $0.27 \mathrm{~d}$ & $0.80 \mathrm{c}$ & $0.24 \mathrm{~d}$ \\
\hline 30 & $47.33 \mathrm{a}$ & $32.3 \mathrm{a}$ & $8.57 \mathrm{a}$ & $6.73 \mathrm{a}$ & $2.93 \mathrm{a}$ & $3.01 \mathrm{ab}$ & $3.12 \mathrm{a}$ & $3.98 \mathrm{a}$ & $0.32 \mathrm{~d}$ & $0.33 \mathrm{~d}$ & $0.32 \mathrm{~d}$ & $0.27 \mathrm{~d}$ \\
\hline F value & 286.76 & $185.06 \mathrm{~b}$ & $55.84 \mathrm{~b}$ & 27.35 & 25.52 & 63.80 & 84.45 & 26.08 & 53.91 & 49.75 & 39.76 & 77.63 \\
\hline
\end{tabular}

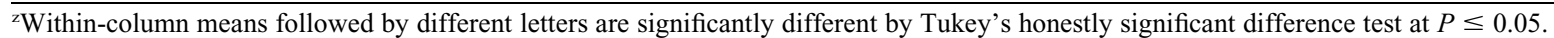

Each value in the table is the mean of six replicates.

Two blocks were pooled for statistical analysis. Block effects were not shown.

Ns, ${ }^{*},{ }^{* *}, * * *$ Nonsignificant or significant at $P \leq 0.05,0.01$, or 0.001 , respectively. 


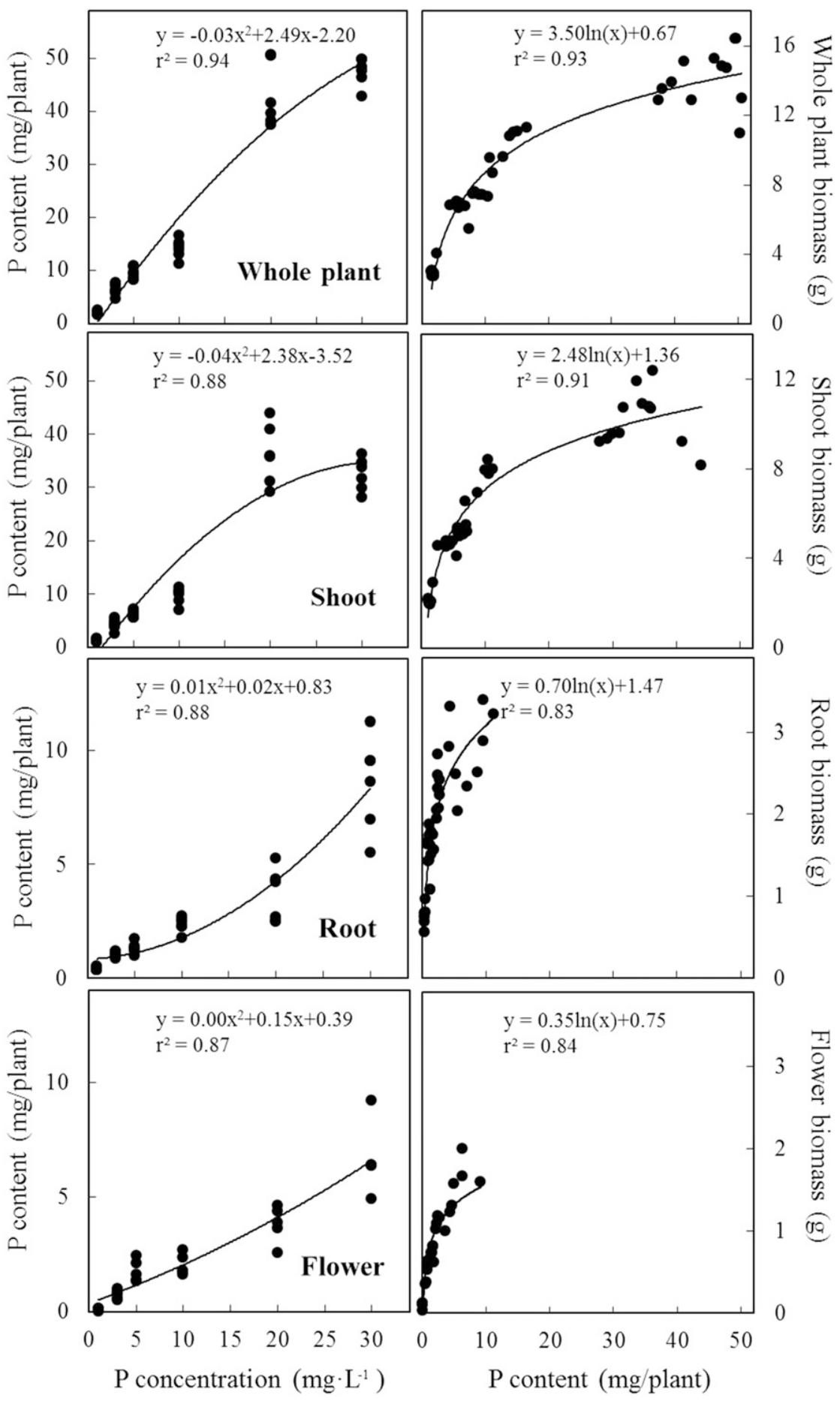

Fig. 5. The effects of $\mathrm{P}$ supply on $\mathrm{P}$ allocation (left column) and dry biomass accumulation (right column) in whole plant, shoots, roots, and flower of lantana. The plants were fertigated with a halfstrength Hoagland's nutrient solution containing $1,3,5,10,20$, or $30 \mathrm{mg} \cdot \mathrm{L}^{-1} \mathrm{P}$ on a regular basis and harvested at 7 weeks after transplanting. Solid lines indicate logarithmic fits to the respective data $(P<0.05)$.

lantana during reproductive stage, and concentrations over this range appear to be superfluous as $\mathrm{P}$ accumulation has little or no influence on biomass gain of plant parts. When $\mathrm{P}$ content was expressed on a dry mass basis, P was favorably accumulated in flowers compared with shoots and roots regardless of the concentration of $\mathrm{P}$ applied. This might be because $\mathrm{P}$ in flowers was diluted by its higher water content in the tissue (averagely 82.5\%) compared with shoot $(71.7 \%)$ and root $(78.9 \%)$ tissues. $\mathrm{P}$ accumulated in lantana flowers might be derived from internal redistribution and remobilization of $\mathrm{P}$ originated from the leaves and/or roots accumulated during the earlier growth period and/or in part directly from the $\mathrm{P}$ applied to the media. The $\mathrm{P}$-deficient roots of common bean retain $\mathrm{P}$ within the tissue without mobilizing it, while
$\mathrm{P}$ in leaves and stems is remobilized to the grain regardless of $\mathrm{P}$ concentrations (Snapp and Lynch, 1996). In perennial species, roots can be an important storage site for nutrients during low growth periods, and the main source of remobilized $\mathrm{P}$ during high growth demand or reproductive periods (Cote and Dawson, 1990).

Thus, the productivity of plants may not be affected even if higher $P$ concentration is applied, increasing potential risks of $\mathrm{P}$ losses to the environment. Similar results were reported in azaleas (Rhododendron L. 'Karen') grown with excess P (25 mg per week) in which $\mathrm{P}$ was mainly stored in leaf and root tissues without increasing plant DW (Ristvey et al., 2007). In their study, it was also reported that higher $\mathrm{P}$ fertilization rates increased $\mathrm{P}$ leaching from the substrate. Because azaleas have low nutritional requirements, an N:P ratio of 20:1 was sufficient for azaleas grown in a commercial potting mix. The fertilization rates of $100 \mathrm{mg} \mathrm{N}$ and $5 \mathrm{mg}$ P per week in their study can be translated into $20 \mathrm{mg} \cdot \mathrm{L}^{-1} \mathrm{~N}$ and $1 \mathrm{mg} P$ per day. Although a direct comparison may not be possible due to the differences in many production components, our results indicate that the $N: P$ ratios of 5:1 and 10:1 are sufficient to maintain the growth of lantana even when inert media are used. If lantana is grown in a commercial mix, a fertilizer with a higher $\mathrm{N}: \mathrm{P}$ ratio may be suitable due to the native $\mathrm{N}$ and $\mathrm{P}$ sources in the media.

The $\mathrm{P}$ requirement is well documented in wheat, in which postanthesis growth is governed by two competing processes: the $\mathrm{P}$ requirements of vegetative tissues to continue normal cellular function and the $\mathrm{P}$ demand of the developing grain (Rose et al., 2007). In our study, $P$ concentration at $10 \mathrm{mg} \cdot \mathrm{L}^{-1}$ appears to meet the needs for the growth and flowering of lantana, which is evidenced by the rapid $\mathrm{P}$ accumulation in shoots over this range (Fig. 5). P concentrations over $10 \mathrm{mg} \cdot \mathrm{L}^{-1}$ strongly stimulated the accumulation of $\mathrm{P}$ in roots and flowers by a magnitude of two to three times without concomitant increase in dry biomass. These results suggest that $\mathrm{P}$ concentration over $10 \mathrm{mg} \cdot \mathrm{L}^{-1}$ is superfluous during the reproductive phase and that DW accumulation of plant parts does not coincide with the amount of $\mathrm{P}$ in these tissues. $\mathrm{P}$ contents could be well above the $\mathrm{P}$ concentrations required for normal cellular function (Veneklaas et al., 2012), and most $P$ contained in plant parts can be released to the environment in the form of waste streams (Raboy, 2009). Thus, careful consideration is needed when applying $\mathrm{P}$ for crop production to reduce the environmental impact and sustainably produce crops.

The PUtE is the amount of biomass produced per unit of acquired $\mathrm{P}$, and is one of the major components of plant $\mathrm{P}$ use efficiency under P limiting conditions (Good et al., 2004; Huang et al., 2011). A higher PUtE of some white clover genotypes was related to a better use of stored $\mathrm{P}$ (Caradus and Snaydon, 1987). P supply to plants is often fluctuating, and therefore, $\mathrm{P}$ remobilization 
within the plant is critical for plant survival (Huang et al., 2008; Vance et al., 2003). The PUtE in shoots, roots, and flowers was negatively correlated with biomass production, and the highest PUtE was observed in P-deficient roots. Plants develop adaptive mechanisms in response to low $\mathrm{P}$, such as changes in morphological or physiological characteristics in roots that may affect $\mathrm{P}$ acquisition (Lynch and Brown, 2006; Raghothama and Karthikeyan, 2005). It was suggested that a higher root-to-shoot ratio may help improve PUtE of plants, especially under P deficiency (Föhse et al., 1988). Such adaptive responses are critical for plants to ensure a satisfactory dry matter production. In our study, we demonstrated that root morphological characteristics of lantana were altered by $\mathrm{P}$ availability. Decreasing $\mathrm{P}$ supply led to an increased specific root length and a higher root-toshoot ratio, and such changes were positively correlated with a higher PUtE $\left(r^{2}=\right.$ 0.54 and 0.12 , respectively; $P<0.05$ ). These characteristics may be associated with a greater exploitation of $\mathrm{P}$ from the rhizosphere and help plants better adapted to $\mathrm{P}$ limitation.

There is no doubt that $\mathrm{P}$ is essential for plant growth and reproduction. Plants require a relatively high $\mathrm{P}$ during the early stages of growth to promote vegetative growth, and sufficient $\mathrm{P}$ supply during reproductive growth to optimize plant productivity. It is important to recognize the roles of $\mathrm{P}$ as a major nutrient element and to properly manage production systems to ensure appropriate concentrations of $\mathrm{P}$ are provided to the developing crop. It entails recognition of $\mathrm{P}$ requirement of a crop, and such changes on $\mathrm{P}$ demand over ontogenetic phases. Our results indicate that minimal rates necessary to support the optimal growth of lantana is $20 \mathrm{mg} \cdot \mathrm{L}^{-1}$ during vegetative stage and $10 \mathrm{mg} \cdot \mathrm{L}^{-1}$ during reproductive stage. Since $P$ requirements could be varied by crops and substrates used for crop production, $\mathrm{P}$ requirements of various horticulture crops should be determined to better manage production systems and to mitigate the environmental concerns.

In summary, our study refines the effects of $\mathrm{P}$ fertilization on plant growth, and provides critical information on the biomass accumulation during vegetative and reproductive growths, in relation to $\mathrm{P}$ accumulation and partitioning in lantana. To obtain high productivity, plants must receive an adequate amount of $\mathrm{P}$ as it is directly related to dry matter accumulation, and the growth stage of a plant needs to be considered when determining an optimum concentration of $\mathrm{P}$. Improved cultural practices will help growers to stay in business while complying with federal and state regulations, which are likely to become more stringent with time.

\section{Literature Cited}

Bailey, D.A. and P.V. Nelson. 2004. Designing a greenhouse crop fertilization program. Department of Horticultural Sciences, North Carolina State University, Raleigh, NC. 1 Jan.
2013. <https://www.ces.ncsu.edu/depts/hort/ floriculture/plugs/fertprog.pdf $>$.

Bjerregård, A. and M. Hansen. 1983. Oversigt over jordanalyser, p. 110. In Jord, vand, næring. ed. Gartnerinfo, Copenhagen.

Bost, T. 2014. Carolinas getting started garden guide: Grow the best flowers, shrubs, trees, vines \& groundcovers. Cool Spring Press, Minneapolis, MN

Bouquet, A.G.B. 1943. Growing tomatoes in the garden. Oregon State System of Higher Education Federal Cooperative Extension Service Oregon State College Corvallis Extension Bulletin 621:1-8.

Broschat, T.K. and A. Klock-Moore. 2000. Root and shoot growth responses to phosphate fertilization in container-grown plants. HortTechnology 10:765-767.

Caradus, J.R. and R.W. Snaydon. 1987. Aspects of the phosphorus nutrition of white clover populations. I. Inorganic phosphorus content of leaf tissue. J. Plant Nutr. 10:273285.

Caradus, J.R., J. van den Bosch, D.R. Woodfield, and A.C. Mackay. 1991. Performance of white clover cultivars and breeding lines in a mixed species sward. 1. Yield and clover content. N. Z. J. Agr. Res. 34:141-154.

Chiera, J., J. Thomas, and T. Rufty. 2001. Leaf initiation and development in soybean under phosphorus stress. J. Expt. Bot. 53(368):473481.

Cordell, D., J.O. Drangert, and S. White. 2009. The story of phosphorus: Global food security and food for thought. Glob. Environ. Change 19: 292-305.

Cote, B. and J.O. Dawson. 1990. Autumnal allocation of phosphorus in black alder, eastern cottonwood, and white basswood. Can. J. For. Res. 21:217-221.

Dufault, R.J. and J.R. Schultheis. 1994. Bell pepper seedling growth and yield following pretransplanting nutritional conditioning. HortScience 29:999-1007.

Epstein, E. and A.J. Bloom. 2005. Mineral nutrition of plants: Principles and perspectives. 2nd ed. Sinauer Associates, Sunderland, MA.

Föhse, D., N. Claassen, and A. Jungk. 1988 Phosphorus efficiency of plants. I. External and internal $\mathrm{P}$ requirement and $\mathrm{P}$ uptake efficiency of different plant species. Plant Soil 110:101-109.

Good, A.G., A.K. Shrawat, and D.G. Muench. 2004. Can less yield more? Is reducing nutrient input into the environment compatible with maintaining crop production? Trends Plant Sci. 9:597-605.

Grant, C.A., D.N. Flaten, D.J. Tomasiewicz, and S.C. Sheppard. 2001. The importance of early season phosphorus nutrition. Can. J. Plant Sci. 81:211-224.

Hansen, C.W. and J. Lynch. 1998. Response to phosphorus availability during vegetative and reproductive growth of chrysanthemum: II. Biomass and phosphorus dynamics. J. Amer. Soc. Hort. Sci. 123:223-229.

Harris, R.W. 1992. Root:shoot ratios. J. Arboriculture 18:39-42.

Havis, J.R. and J.H. Baker. 1985. Phosphorus requirement of Rhododendron 'Victor' and Cotoneaster adpressa grown in a perlite-peat medium. J. Environ. Hort. 3:63-64.

Hoagland, D.R. and D.I. Arnon. 1950. The waterculture method for growing plants without soil. Univ. Calif. Coll. Agr. Expt. Sta. Circ. 347353.

Huang, C.Y., N. Shirley, Y. Genc, B. Shi, and P. Langridge. 2011. Phosphate utilization efficiency correlates with expression of lowaffinity phosphate transporters and noncoding RNA, IPS1, in barley. 2011. Plant Physiol. 156(3):1217-1229.

Huang, C.Y., U. Roessner, I. Eickmeier, Y. Genc, D.L. Callahan, N. Shirley, P. Langridge, and A. Bacic. 2008. Metabolite profiling reveals distinct changes in carbon and nitrogen metabolism in phosphate-deficient barley plants (Hordeum vulgare L.). Plant Cell Physiol. 49:691-703.

Hunt, R. 1990. Basic growth analysis. Unwin Hymin, London, UK.

Kim, H.J., J.P. Lynch, and K.M. Brown. 2008. Ethylene insensitivity impedes a subset of responses to phosphorus deficiency in tomato and petunia. Plant Cell Environ. 31:17441755.

Lynch, J., A. Uäuchli, and E. Epstein. 1991. Crop physiology and metabolism. Vegetative growth of the common bean in response to phosphorus nutrition. Crop Sci. 31:380-387.

Lynch, J. and K. Brown. 2006. Whole plant adaptations to low phosphorus availability, $\mathrm{p}$. 209-242. In: B. Huang (ed.). Plant-environment interactions, Taylor \& Francis, Boca Raton, FL.

Majsztrik, J.C., A.G. Ristvey, and J.D. Lea-Cox. 2011. Water and nutrient management in the production of container-grown ornamentals. Hort. Rev. 38:253-296.

Marschner, H. 2012. Mineral nutrition of higher plants. 3rd ed. Academic Press, San Diego, CA.

Melton, R.R. and R.J. Dufault. 1991. Nitrogen, phosphorus, and potassium fertility regimes affect tomato transplant growth. HortScience 26:141-142.

Murphy, J. and J.P. Riley. 1962. A modified single solution method for the determination of phosphate in natural waters. Anal. Chim. Acta 27:31-36.

Nelson, P. 1996. Macronutrient fertilizer programs. In: D.W. Reed (ed.). Water, media and nutrition for greenhouse crops. Ball Publ., Batavia, IL.

Raboy, V. 2009. Approaches and challenges to engineering seed phytate and total phosphorus. Plant Sci. 177:281-296.

Raghothama, K.G. and A.S. Karthikeyan. 2005. Phosphate acquisition. Plant Soil 274:37-49.

Ristvey, A.G., J.D. Lea-Cox, and D.S. Ross. 2007. Nitrogen and phosphorus uptake efficiency and partitioning of container grown azalea during spring growth. J. Amer. Soc. Hort. Sci. 132:563-571.

Rose, T.J. and M. Wissuwa. 2012. Rethinking internal phosphorus utilization efficiency (PUE): A new approach is needed to improve PUE in grain crops. Adv. Agron. 116:185217.

Rose, T.J., Z. Rengel, Q. Ma, and J.W. Bowden. 2007. Differential accumulation patterns of phosphorus and potassium by canola cultivars compared to wheat. J. Plant Nutr. Soil Sci. 170:404-411.

Snapp, S.S. and J.P. Lynch. 1996. Phosphorus distribution and remobilization in bean plants as influenced by phosphorus nutrition. Crop Sci. 36:929-935.

Van der Boon, J. 1981. A slow-release fertilizer for nursery plants in container. Acta Hort. 126:321-348.

Vance, C.P., C. Uhde-Stone, and D.L. Allan. 2003. Phosphorus acquisition and use: Critical adaptations by plants for securing a non renewable resource. New Phytol. 157:423-447.

Veneklaas, E.J., H. Lambers, J. Bragg, P.M. Finnegan, C.E. Lovelock, W.C. Plaxton, C.A. Price, 
W. Scheible, M.W. Shane, P.J. White, and J.A. Raven. 2012. Opportunities for improving phosphorus-use efficiency in crop plants. New Phytol. 195:306-320.

Warncke, D.D. and D.M. Krauskopf. 1983. Greenhouse growth media: Testing and nutrition guidelines. Mich. State. Univ. Coop. Ext. Bul. E-176.

Weston, L.A. and B.H. Zandstra. 1989. Transplant age and $\mathrm{N}$ and $\mathrm{P}$ nutrition effects on growth and yield of tomatoes. HortScience 24:88-90.

Whitcher, C.L., M.W. Kent, and D.W. Reed. 2005. Phosphorus concentration affects New Guinea impatiens and vinca in recirulating subirrigation. HortScience 40:20472051.

Williams, K.A. and P.V. Nelson. 1996. Modifying a soilless root medium with aluminum influences phosphorus retention and chrysanthemum growth. HortScience 31:381-384.

Wright, R.D. and A.X. Niemiera. 1987. Nutrition of container-grown woody nursery crops. Hort. Rev. 9:75-150.

Yeager, T.H. and R.D. Wright. 1982. Phosphorus requirement of Ilex crenata Thunb. cv. Helleri grown in a pine bark medium. J. Amer. Soc. Hort. Sci. 107:558-562. 